\title{
The book review business
}

\author{
Most science journals include book review pages. Tim Lincoln discusses \\ what there is in the book review for a book's publisher and author, \\ the reviewer, and the journal and its readers.
}

REPORTS of the death of the book have been exaggerated, not least in science. Last year in Britain over 48,000 books were published. Of these 11,000 came into the category of science, technology and medicine (STM).

Some of the new books among the 11,000 were no doubt dross, some jewels. Those judgements, and others in between, will in due course be confirmed by low or high sales and perhaps the eventual compliment of a second edition. More immediately they are to be found in the review pages of periodicals, science journals among them. What is there in the book review business for the four principals concerned - the publisher; the author or editor of a book; the reviewer; and the journal and its readers?

Of the four, it is publishers who would seem to have the clearest reason for wanting to see several inches of (preferably prompt and laudatory) comment upon one of their books. Publishers, the cynic would say, are simply in the business of selling a product and that publishers seek reviews because reviews sell books. Like everyone else the cynic is guessing. No one knows whether good reviews sell books, whether bad ones stop them selling, or indeed whether reviews affect sales much at all. Trade publishing mythology speaks of "selling reviews" by the likes of Arnold Bennett and Bernard Levin, but it seems unlikely that a review of Volume 13 of Advances in Toluene Research, appearing a year after the book's date of publication, will bring a glint to librarians' eyes and their hands to the cash box. Besides, the biggest STM publishers have such a tight grasp of their mailing lists that the review as a vehicle for selling may be superfluous.

Sending out review copies is expensive. Given the ratio of review space to books published, many of them gather dust in editorial offices and may eventually be interred on the shelves of a second-hand bookshop. Reviews must surely help the sales of some books; and they at least advertise the subject areas in which a publisher is active. But from the publishers' viewpoint there are further reasons why the review ritual continues. First, perhaps, simply because it is a ritual. More positively, publishers genuinely and justly look for constructive criticism of their "product" from as many impartial sources as possible. (That is why it is such a dreadful sin for a reviewer to pronounce on the same book in different publications; review space is hard won.) For publishers, however, perhaps the most compelling reason for seeking reviews is that an author without a review is an unhappy author.

Cynicism apart, publishers need to make a profit. They like also to publish respectable books that are well-received in public. Conversely academic authors also like to make money but their greater need may be to write good books. Perhaps a few colleagues will have commented upon some of the chapters at manuscript stage or may even have written some of them. Whatever the form of the book, however, or the motive behind writing or compiling it, it is understandable that any author or editor should wonder "How did I do?". The corollary is that the question should be echoed and answered in print in the form of a review. There are to be sure a few books which nobody seems to care about, the symposium proceedings' volume usually being among them. But more often an author has put not a little bit of his or her soul into the writing of a book. In this respect it is a solemn task that reviewers have pressed upon them, though one of which authors historically have taken a poor view.

Reviewers, according to Shelley, "with some rare exceptions are a most stupid and malignant race'. Samuel Coleridge was more scornful: "Reviewers are usually people who would have been poets, historians, biographers. . . if they could". Scientists as book reviewers are usually spared such libels, the harsh comments applying not to all of the diverse forms of reviewing but to arts' criticism and most especially to professional critics. Snug in peer review, science and the STM book lack such critics. Even though the peer book review too is the norm - for the good reason that STM books are so technical in content and language - it is nonetheless here that there is a happy oddity in the practice of science.

Custom decrees that in book reviews it is usual for a reviewer to put his name publicly to an evaluation of the work of others. By contrast, a different tradition dictates that much of the rest of criticism in science should be anonymous, for example in the appraisal of grant applications and refereeing of papers. It is true that there are iconoclasts in the second respect, yet in being signed the book review is an anomaly. It is at the same time a respected anomaly, so that when a journal invites someone to pontificate in print on a book, that person will often agree. But why?

The most conspicuous motives for taking on the chore of a book review - the mercenary and the self-serving - are also the most superficial. There is the lure of possessing the review copy, the standard incentive and often quite a prize when the $£ 50$ academic book is not uncommon. There is also the opportunity of selfpublicity, or of riding a hobby-horse. And there may be a fee, though reviewing academic books even less than writing them is financially unrewarding. All of these may weigh in the decision. Yet there is a more general and powerful reason. Most often reviewers commit themselves to read a book, and write about it, as an extension of their academic duties and as an exercise in self-education. The imposed discipline of copy deadline and word limit may or may not be a necessary goad. The result is nevertheless that some-of-those-bookswhich-ought-to-be-read are read, and read not merely their pages turned. The beneficiary of such labour is not only the reviewer; whether in exposing delusion or unearthing treasure, the journal and its readers are also served.

All of this is the earnest stuff of scholarship, but at its best a review earns space in the books' pages not merely. by cataloguing the chapters in the volume and critically evaluating them, but through the extra quality of general interest and the intangible merit of "readability". Quite obviously a book such as Lewis Thomas's The Youngest Science (reviewed on p.778), about which there is a story to be told, allows that third function to be taken further than the apocryphal Volume 13 of Advances in Toluene Research. Equally, greater discursiveness is made possible by a limit of 2,000 rather than 200 words. Nonetheless that a brief review of a scholarly book can be illuminated by wit, learning and pungent asides is shown in the review pages of a number of specialist journals.

The mandate of a reviewer is inordinately difficult: to describe a book; to assess it; to inform generally; and perhaps to entertain. All this for love rather than money. It is galling for a reader and more so for an author of a book to find in several hundred words no mention of the work supposedly under review. In such an instance the reviewer has done a disservice to both parties. Yet the author should not complain if his book, as well as being judged implicitly or explicitly, has been used as a stage from which to enlighten, amuse or provoke. The reviewer may not have succeeded entirely in blending the functions of a review, but that is a measure of the difficulty of the task.

Oscar Wilde's approach to book reviewing was first to write the review, then, if he liked it, to read the book. That is not to be recommended; priority should go to assessment of the volume under consideration. But Wilde's technique does have a tinge of merit.

Tim Lincoln is the Book Review Editor of Nature. 